\title{
Does decentralized decision making increase company performance through its infrastructure Information Technology investment?
}

\begin{abstract}
A company's Information Technology (IT) infrastructure is a key factor in its sustainability and ongoing success and profitability. This paper explores the relationship between a company's investment in IT and its performance. Performance is measured, with the help of a Balanced Scorecard (BSC), in four ways; financial, internal business processes, innovation \& learning and customer perspective. The relationship between each BSC category serves as indicators of the effect of IT investment on a company's performance. This will help establish the benefits of both financial and non-financial indicators. We focus on the Electrical and Electronic manufacturing performance of companies Malaysia. System Resource Theory (SRT) is used as the background theory to explain the concepts of organizational effectiveness, efficiency, productivity and multidimensional performance measurements and to link the variables used in this study. We conduct an empirical study in order to confirm the moderating effects of decentralized decision making. The results suggest that IT investment produces a significant relationship with all BSC perspectives, but the moderating effect is only significant only from a customer perspective.
\end{abstract}

Keywords: $\quad$ balanced scorecard; infrastructure IT investment; decentralized decision making; moderating effects; multidimensional company performance; System Resource Theory 


\section{Does decentralized decision making increase company performance through its infrastructure Information Technology investment?}

\subsection{Introduction}

Many companies invest heavily in Information Technology, often not receiving the expected return on their investment (Brynjolfsson, 1993; Peppard \& Rowland, 1995). These large expenditures have led to managerial concerns over the business value of IT (Lee, Chunhui \& Siew, 2010). The link between IT investment and a firm's performance has been discussed in the scientific literature (Bardhan, Krishnan \& Lin; 2013) and the 'productivity paradox' has been an ongoing debate for a number of years (Barua, Kriebel \& Mukhopadhyay, 1995; Brynjolfsson, 1996; Brynjolfsson \& Hitt, 1996; Hitt \& Brynjolfsson, 1996; Bharadwaj, Bharadwaj \& Kosynski, 1999; Garud \& Kumaraswamy, 2005; Thouin, Hoffman, Ford, 2008; Yuhn \& Park, 2010). Managerial proficiency in resource utilization and organizational control is reflected in a firm’s productivity and performance (Kohli, Devaraj \& Ow, 2012). These studies provide much of the motivation for this paper.

\subsection{Related work}

\subsection{IT Productivity Paradox}

The benefits of IT investment have received interest among scholars and practitioners. Many studies have investigated the return on IT investment with regard to a company's performance, with conflicting conclusions being reported (Sircar, Turnbow \& Bordoloi, 2000; Barua, Kriebel \& Mukhopadhyay, 1995; Brynjolfsson, 1996; Brynjolfsson \& Hitt, 1996; Hitt \& Brynjolfsson, 1996; Bharadwaj, Bharadwaj \& Kosynski, 1999; Barua \& Mukhopadhyay, 2000; Dedrick, Gurbaxani \& Kraemer, 2003; Hoadley \& Kohli, 2014; Kohli \& Devaraj, 2003; Kohli et al., 2012; 
Barua \& Kreibel, 1995; Hitt \& Brynjolfsson, 1996). Some noted positive relationships between IT investment and company performance, others did not. Discussions regarding IT productivity and the strategic value IT still continues (Hwang, Kim \& Lee, 2015). Despite these uncertainties, companies continue to invest in IT, presumably as they perceive value in doing so, or perceive that they would be at a disadvantage if they did not make these investments.

The term productivity is defined as the output produced for a given input (Brynjolfsson, 2003; Hitt \& Brynjolfsson, 1995). While it is simple to define, it is difficult to measure. For example, the measurement used for output will not only include the physical products produced but also the value created for consumers. In today's economy, value depends increasingly on product quality, timeliness, customization, convenience, variety, and other intangibles (Brynjolfsson \& Hitt, 1993). Difficulties also exist in measuring the input as there are many factors to be considered, such as capital equipment, materials and other resources consumed (Brynjolfsson \& Hitt, 1993). IT is perceived as an enabler to improve productivity, although IT investment comes with no guarantees (Lin \& Chuang, 2013). Many companies assume, that by investing in IT, it will create a positive economic returns to them but the inconsistencies reported in the scientific literature have led to the productivity paradox. Within the manufacturing sector, which is the focus of this study, IT-driven productivity growth in the 1990s may have been more pronounced in manufacturing than in the non-manufacturing sector (Stiroh, 2002).

This paradox can be defined as the perception that there is a lack of increase in output, after an investment in IT (Sircar et al., 2000). These findings were later contradicted (Brynjolfsson \& Hitt, 1995, 1996; Dewan \& Min, 1997; Garud \& Kumaraswamy, 2005; Thouin, Hoffman, Ford, 2008; Yuhn \& Park, 2010). One of the most significant gaps in the study of the productivity 
paradox is too much emphasis on United States (US) firms and the lack of cross-country studies (Melville, Kraemer \& Gurbaxani, 2004) and this suggests that further research on this issue is needed outside the US. Some researchers argue that IT investment relates indirectly to a firm's performance through contextual factors (Campbell, 2012), such as country characteristics (Lin \& Chiang, 2011). Studying companies from outside the US business environment will provide additional perspectives.

\subsection{Infrastructure IT Investment}

IT investment is often a large investment for a firm. On average more than $4.2 \%$ of revenue is invested in IT (Weill, Subramani \& Broadbent, 2002). IT investment also forms a major portion in capital budgets in many organizations (Jeffery \& Leliveld, 2004). IT investment is an enormous and significant spending by a firm (Bureau of Economic Analysis, 2007). The average company normally allocate $54 \%$ of its IT investment to infrastructure (Weill et al., 2002). IT infrastructure investment is defined as the investment for the purpose of managing shared IT services used by multiple applications such as servers, networks, laptops, customer databases etc. (Weill \& Aral, 2003; 2004). A good quality IT infrastructure is a complex fusion of technology, processes and human assets (Barney, 1991). However once in place, it can lead to a competitive advantage because it will take competitors time to emulate it (Weill et al, 2002).

\subsection{Performance Measurement - Balanced Scorecard}

The scientific literature suggests that the use of multiple measures of performance, including both financial and non-financial, are important to capture the non-financial benefits from an investment in IT. Companies are now using performance measurement systems to track non- 
financial metrics (Banker, Chang \& Pizzini, 2004; Fernandes, Raja \& Whalley, 2006; Barad \& Dror, 2008).

The assessment of organizational performance could be a catalyst for both the present and future success of companies (Kaplan \& Norton, 1996). The Balanced Scorecard (Kaplan \& Norton, 1992) brings together elements of strategy, financial and non-financial measures. This methodology enables companies to translate their strategic objectives into a coherent set of performance measures (Kaplan \& Norton, 1993). The Balance Scorecard links strategy to organizational measurement and is frequently used by managers in their decision making. It is regarded as one of the most significant accounting developments (Tayler, 2010), enabling managers to make decisions that can maximize a company’s financial value (Kaplan, 2009).

Technology influences the structure of industries, creates competitive advantage and has the potential to change the rules of competition. Moreover, nearly every function within an organization has technology integrated within it, including production, procurement, distribution, accounting and marketing (Edwards, 2001). Previous studies suggest that IT enables organizational change that leads to productivity gains and it should not only be viewed as a tool for automating current processes (Mithas, Tafthi, Bardhan \& Goh, 2012). The effectiveness of technology, and information processing in particular, are very important to a company's success and it is a misconception to consider IT as just another department within an organization. Furthermore, the application of IT is an integral part of a company's strategy and it affects many parts of the business (Edwards, 2001).

The purpose of the Balanced Scorecard (BSC) is to translate strategy into measures that uniquely communicate vision to the organization (Kaplan \& Norton, 1992). BSC was developed to; (1) 
clarify and translate vision and strategy, (2) communicate and link strategic objectives and measures, (3) plan, set targets and align strategic initiatives and (4) enhance strategic feedback and learning. It also assists in realizing both tangible and intangible benefits of any investment made (Kaplan \& Norton, 1992; 1993; 1996; 2001). Kaplan and Norton's Balanced Scorecard originally developed as a tool for performance measurement at the organizational level (Kaplan \& Norton, 1992). This was followed by further developments with regard to concept and applications (Kaplan \& Norton, 1993, 1996, 2001). Several researchers have empirically studied BSC (Hoque \& James, 2000; Hoque, Mia \& Alam, 2001; Maiga \& Jacob, 2003, Fang \& Lin, 2006). The details of the empirical studies on BSC are as explained below.

It was posited that BSC usage was related to improved performance, but factors such as organization size, product life cycle, or market position did not significantly influence it (Hoque \& James, 2000). The outcome stated the relationship between multidimensional performance measurement to businesses facing high competition and making greater use of computer-aided manufacturing processes (Hoque, Mia \& Alam, 2001). The study concerned with the complimentary effect of BSC \& Activity Based Costing (ABC) on manufacturing performance and the findings suggested the association of ABC \& BSC in affecting performance (Maiga \& Jacob, 2003). This study measured ERP performance using BSC approach and a comprehensive set of key perspectives were used to assess the firm's performance using BSC approach (Fang \& Lin, 2006).

The main concept outlined in BSC is to translate the company's vision and objectives into strategic actions which can be measured. According to Edwards (2001), a properly developed Balanced Scorecard should have cause and effect relationships, and link to financials, performance drivers and measures that create change. Performance measures should be explicitly 
linked in hypothesized cause and effect relationship that depicts the company's strategy (Kaplan \& Norton, 2004).

For example, training employees should lead to shorter production times, which in turn leads to shorter delivery times. These all lead to a return on the investment made (Ruzita, Daing Nasir, Yuserrie, 2006). BSC emphasizes the future performance drivers instead of solely relying on financial indicators. If the indicators are good then these will be reflected in financial indicators. BSC has been found to be suitable to measure business performance due to its success in being able to align competitiveness indicators with business objectives (Oztaysi \& Sari, 2009; Öztayşi, Kaya \& Kahraman, 2011).

Previous studies on the business benefits of IT investments have found that IT has a range of performance measures including productivity (Brynjolfsson, 1996), market valuation (Dos Santos \& Pfeffers, 1995; Brynjolfsson \& Yang, 1997; Bharadwaj et al., 1999), consumer welfare (Hitt \& Brynjolfsson, 1996; Brynjolfsson, 1996) and operating performance (Barua et al.,1995; Zhu \& Kraemer 2002). These studies motivate this research to further investigate the potential benefits that can be obtained from IT investments, be that via financial and nonfinancial indicators, or by using the multidimensional performance measures of the balance scorecard.

\subsubsection{Financial Perspective}

Using BSC, and aligning internal business processes, customer and innovation \& learning perspectives, should provide a financial return on investment (Trang, 2016). Some of the financial benefits that have been realised include reducing costs (Weill \& Broadbent, 1998), increasing productivity (Turner \& Lucas, 1985), increasing revenue (Weill \& Aral, 2004) and 
assisting other functions such as accounting and budgeting (Weill, 1992). Operating income has also been used in previous studies (Fang \& Lin, 2006), with others focussing on performance (Mabert, Soni \& Venkatarmanan, 2000; Davenport, 1993); sales growth (Stratopoulus \& Dehning, 2000) and return on investment (Bradford \& Robert, 2001). The measures used in this study are operating income, sales growth and return on investment.

The use of these measures is consistent with prior research on performance, IT investment and systems (Mabert et al., 2000; Davenport, 1993; Stratopoulus \& Dehning, 2000; Bradford \& Robert, 2001; Fang \& Lin, 2006). Since this study employs the BSC in the manufacturing sector, it is important to have measures that are recognized in this sector. These measures have been used in this setting (Hoque et al, 2001).

Additionally, the focus of this study is to ascertain the benefits derived from IT investment to manufacturing performance. Operating income and sales growth will be indicative of the financial benefits that could be obtained (Strassman, 1999). This return on investment will measure not only the financial benefits but also increased productivity.

\subsubsection{Internal Business Processes}

An emphasis should be placed on internal business processes as it is these that creates the product. Managers need to focus on those critical internal processes as it enables them to satisfy customer needs. Internal business processes are concerned with using resources as efficiently as possible and determining their competitive performance for future business endeavours (Hoque et al., 2001). It also ensures that the main processes are generating value and that business objectives are being met (Lawrie \& Cobbold, 2004). 
Some of the benefits of an investment in IT were greater business processing and management (Weill \& Woodham, 2002), leading to increased quality (Weill \& Aral, 2006). This study adopts the specific measures used in manufacturing such as material efficiency variance, ratio of good output to total output, labour efficiency variance, manufacturing lead time and rate of material loss (Hoque et al., 2001).

\subsubsection{Innovation and Learning}

Innovation and learning aims for continuous improvement so that companies can adapt to changing demands by creating new products that meet the needs of their customers. In order for companies to survive in a dynamically and changing environment, they must always be creating new products, improving existing products and learning to cope/adapt with changing situations. Only when these are done, will they be able to survive in by penetrating new markets, increasing market share and increasing profitability (Kaplan \& Norton, 1992).

Organizations are increasingly turning to IT for their employee training (Westerman, 2004). Training of employees is key factor for employee satisfaction as it develops employee skills (Sami, 2010) and provides a process for continuous professional development.

Some of the gains recorded from IT investments enable future IT initiative and flexibility, increased innovation and positioning organizations for growth from modified and enhanced products (Weill \& Aral, 2004). IT can also facilitate better business management (Weill \& Woodham, 2002), increased productivity (Turner \& Lucas, 1985) and better process innovation (Weill \& Broadbent, 1998).

Specific measures proposed in previous manufacturing and information system research are the number of new patents (Hoque et al, 2001), the number of new products launched 
(Grover \& Davenport, 2001), the time to market for new products (Hoque et al, 2001) and employee satisfaction (Sami, 2010).

\subsubsection{Customer Perspective}

The purpose of this measure is to assess customer satisfaction. In a competitive market, customers must be satisfied, or market share will drop. Customers are also concerned about price, faster and reliable deliveries, design, quality and service levels (Hoque et al., 2001). In this study customer perspective was conceptualized as the leading measure that included nonfinancial terms that could help to satisfy customer needs. They may be leading indicators of what the financial measures will subsequently reveal, for example, increases in customer satisfaction would lead to sales growth and hence financial performance.

Some of the benefits of taking into account the customer perspective were IT serving as a source of competitive advantage (Weill et al., 2002), having a shared customer database (Weill \& Aral, 2003), reduced time to market for new business initiatives (Weill \& Aral, 2004), analyzing customer needs so that better decisions could be made taking into account customer needs (Weill \& Aral, 2006) and promote better interaction between companies and their customers.

The measures used in this study are consistent with prior manufacturing and information system research, and include market share (Hoque et al, 2001), customer response time (Grover \& Davenport, 2001), on time delivery (Appleton, 1997), number of customer complaints (Hoque et al., 2001), number of warranty claims (Hoque et al, 2001), survey of customer satisfaction (Fang \& Lin, 2006), percentage of shipments returned due to poor quality (Hoque et al, 2001) and number of overdue deliveries (Hoque et al, 2001). 


\subsection{Decentralized Decision Making}

There is a significant positive correlation between IT and a decentralized structure, but when IT and decentralization were measured simultaneously, there was no evidence of causality on the relationship (Andersen \& Segars, 2001). There is no direct relationship between decentralized strategic decision making and a company's performance (Andersen, 2005), implying that decentralization cannot be used as an independent variable. Motivated by these observations, it is the objective of this study to suggest that there is an indirect relationship, making decentralization a moderator on the relationship between IT, decentralization and a company's performance. The relationship between IT investment and company performance has produced both positive and negative results, suggesting the need for the moderator to strengthen the relationship. The conflicting conclusions identified earlier provides motivation for additional research. Moderating variables are typically introduced when there is unexpected or inconsistent relationship between a predictor and a criterion variable (Baron \& Kenny, 1986).

The control variable of the number of employees is also considered so as to determine whether company size would affect the relationship between IT investment and company performance. This study addresses the following three research questions;

RQ1. What is the relationship between a company's IT investment and the company's performance?

RQ2. What is the effect of size on the relationships between IT investment and manufacturing company performance?

RQ3. Is the relationship between a company's IT investment and the manufacturing company's performance moderated by decentralized decision making? 
The primary contributions of this research are as follows. i) It investigates the effects of IT investment and its relationship with the four perspectives of the balanced scorecard (BSC). ii) It explores the moderating effect of decentralized decision making on the relationship between IT investment and a company's performance. The three main areas to be investigated in this study are as follows:

- IT investment tends to be significant and can lead to managerial concerns over the business value of IT (Lee et al., 2010). Evaluating the benefits from IT investment, and ascertaining, whether it will bring the expected benefits is worthy of investigation.

- Investigations into the productivity paradox has had an 'emphasis on United States (US) firms' and has shown a 'lack of cross-country studies'. This has meant that the 'results are conditional on the characteristics of the US business environment' (Melville et al., 2004). In this study, we use samples from outside the US, which enables us to gauge if the finding reflect those from previous US studies.

- This study extends previous studies on decentralization (Andersen \& Segars, 2001; Andersen 2005). Decentralized decision making is conceptualized to act as a moderator to the relationship between categorizations of IT investment and company performance.

\subsection{System Resource Theory}

A system resource approach (Yuchtman \& Seashore, 1967) is utilised in this paper to study the productivity paradox in an effort to understand organizational effectiveness. In this theory, organizational effectiveness looked at the firm itself as the main reference and it would generally explain the variables which were related to organizational effectiveness (Mahmood \& Mann, 1993). 
System resource theory proposes organizational effectiveness will depend on how organizations can acquire and utilise resources in order to achieve organizational effectiveness (Yuchtman \& Seashore, 1967). Organizational effectiveness as defined here is the maximization of ability and optimal use of resource in order to derive the maximum benefits from it and to achieve organizational effectiveness (Yuchtman \& Seashore, 1967; Katz \& Kahn, 1966). According to this theory, the phases involved in explaining organizational effectiveness are input, process and output (Yuchtman \& Seashore, 1967).

Several authors (Mahmood \& Mann, 1993; Brynjolfnsson \& Hitt, 1993) have conceptualized IT investment as an input, in line with this approach. Input was defined as the acquisition of resources, helping the company attaining organizational effectiveness. Previously IT had been regarded as a resource to a company (Barney, Wright \& Ketchen, 2001; Wu, Yeniyurt, Kim \& Cavusgil, 2006).

This theory proposed that organizational effectiveness must not be assessed using single criterion only, but must include an open ended multidimensional set of criteria (Yuchtman \& Seashore, 1967). The issue of organizational effectiveness had been much researched by previous scholars especially from researchers in the social science discipline (Cameron, 1986, Katz \& Kahn, 1966). Effectiveness was conceptualized in terms of resource viability rather than in terms of specific task objectives (Yuchtman \& Seashore, 1967).

The distinction between a goal centered view and a system resource view when evaluating effectiveness is in the way effectiveness was measured by determining the task objectives and developing criterion measures to assess how far the objectives have been achieved 
(Hamilton \& Chervanny, 1981). An example was given to compare between actual benefits and costs with budgeted figures.

As for the system resource view, effectiveness is attained when achieving standards of good practices and this view fulfils other functions and has other consequences besides just meeting objectives (Hamilton \& Chervanny, 1981). Different conceptualizations exist for different departments. In a human resource department for instance, its effectiveness could be assessed by looking at the nature of communication and conflict between MIS and user personnel, user participation in system development, or user job satisfaction and for technological resources. The quality of the system or service levels might indicate the level of system effectiveness (Hamilton \& Chervanny, 1981). As a conclusion, a system resource approach states that there are other functions and consequences which need to be considered instead of focusing solely on achieving objectives and these needs have to be taken into account when measuring effectiveness (Hamilton \& Chervany, 1981).

With regard to the productivity paradox, Mahmood \& Mann (1993) have used the System Resource Approach theory as the framework for their study. Effectiveness in their study was measured using the key financial ratios which are extended in this study by using financial and non-financial indicators in assessing organizational effectiveness.

\section{HYPOTHESES DEVELOPMENT}

\subsection{Relations between Infrastructure IT investment with firm performance}

IT infrastructure investment provides a foundation for shared IT services which can be used by multiple applications such as servers, networks, database (Weill \& Aral, 2003). Since it is the backbone of any IT initiatives, many advantages are obtained by using it, such as reducing 
cost through standardization and consolidation (e.g. server or data centre consolidation), providing a platform for delivering company wide initiatives, such as a shared customer database, to enable future IT initiatives and flexibility such as modular architectures and also to reduce time to market for new business initiatives (Weill \& Aral, 2004).

Other benefits of infrastructure investments were business integration, business flexibility, reduced marginal costs and standardization (Weill \& Broadbent, 1998). IT Infrastructure will facilitate the linkages between the company and its business partners, external infrastructures such as bank payment systems, and to public infrastructures such as the Internet (Weill et al., 2002). Internally, company managers can use the IT infrastructure to facilitate better business processing and management. IT infrastructure is an important factor in determining the speed with which new business initiatives can be implemented (Weill \& Woodham, 2002).

Although investment in IT infrastructure can create high up front cost and long benefit time horizons (Duncan, 1995; Weill \& Broadbent, 1998), it also enables new applications and functionality and helps achieve long term performance targets (Duncan, 1995).

The benefits from having an IT infrastructure in the company, and its stakeholders, to its performance can be summarized in the Table 1.

\section{Table 1}

\section{Benefits of IT infrastructure}

\section{Benefits}

\section{Performance Perspective}

1 Reducing cost (Weill and Financial Perspective




\begin{tabular}{lll}
\hline & $\begin{array}{l}\text { linkages with bank payment } \\
\text { system (Weill et al., 2002). }\end{array}$ \\
\hline 2 & $\begin{array}{l}\text { Facilitate greater business } \\
\text { processing and management } \\
\text { (Weill \& Woodham, 2002). }\end{array}$ \\
\hline
\end{tabular}

3 Source of competitive advantage Customer Perspective

(Weill et al, 2002; platform for a shared customer database (Weill \& Aral, 2004); to reduce time to market for new business initiatives (Weill \& Aral, 2004).

4 To enable future IT initiative and Innovation and Learning flexibility (Weill \& Aral, 2004)

IT investment is the basis for any company’s IT initiatives. It is posited that IT investment would improve all perspectives as stated in BSC measures. Various researchers have emphasized the differential performance effects of IT investment and infrastructure IT investment, and this is summarized in Table 2.

\section{Table 2}

Other authors linking IT to performance

\section{Researchers \\ Benefits}

Benjamin, 1993; Broadbent \& Butler, 1995; Davenport 1993; Earl \& Kuan 1994)
IT is a potential enabler of change where the capabilities of IT infrastructure are required to integrate capabilities crossing business and functional unit boundaries so that it can enable better business processes which in the end lead to better performance. 
Duncan, 1995

Brynjolfsson, 1996

Bharadwaj, Bharadwaj

\& Kocynski, 1999

Hitt \& Brynjolfsson, 1996

Zhu \& Kraemer (2002)

Sambamurthy, Bharadwaj \& Grover, 2003.
Infrastructure IT investment enable new applications and functionality, and lay the groundwork for significant long term performance improvements.

Productivity

Market Valuation

Consumer welfare

Operating performance

IT investment to contribute directly to product innovation

Thus, the hypothesis formulated in this study in relation to IT infrastructure investment are as follows:

H1a: Company's emphasis on infrastructure IT investment is positively related to the company's financial performance.

H1b: Company's emphasis on the infrastructure IT investment is positively related to the company's internal business process performance.

H1c: Company's emphasis on the infrastructure IT investment is positively related to the company's innovation and learning performance. 
H1d: Company's emphasis on the infrastructure IT investment is positively related to the company's customer performance.

\subsection{Moderating Roles of Decentralized Decision Making}

The arguments presented in preceding sections support the notion that decentralized decision making would moderate the relationship between IT investment and a company's performance. This section will outline how decentralized decision making moderates the causal relationship between IT investment and a company’s performance.

Decentralization provides faster and better responsive actions in situations that could influence the company's strategic path (Mintzberg, 1978; Burgelman, 1983), which may lead to improved decisions, and hence performance. Middle managers, in their decentralized nodes, could provide accurate and relevant insights which are needed in order to deal with changing environmental conditions (Huber, 1990). A decentralized structure will facilitate faster decisionmaking and better adaptability to conditions prevalent in local markets (Khan, 2012). Therefore, the decisions of lower level management are often based on better information. This further supports that decentralized decision making by way of providing accurate and relevant insights will lead to faster and more informed decisions that will moderate the causal relationship between IT investment and company performance.

The combinations of effective decision making within an electronic communication network will facilitate flexible exchange of information across functional boundaries that can improve innovation and performance (Hency, 1992; Kogut \& Zender, 1992; March, 1991). By having improved communication capabilities that can reduce an organization's information 
processing costs, the organizational procedures can be more cost effective (Andersen \& Segars, 2001).

Other ways decentralized structure can influencing or moderate the relationship of IT investment and company performance are through the effectiveness of decentralized decision makers identifying the problems and opportunities faster (Andersen \& Segars, 2001). When these are identified, the computerized information system will support the gathering of data and provide a faster reaction to emerging events which should lead to more profitable business decisions and performance (Andersen \& Segars, 2001). A decentralized decision structure can make the company more effective and enhance its responsiveness (Fulk \& Desanctis, 1995).

Decentralized structures will improve access to information and, coupled with enhanced communication in computerized network, lead to an increase in innovative capacity (Nonaka, 1994). Decision makers can easily obtain data and information about business activities and sharing it can result in more effective responses (Andersen \& Segars, 2001). The usage of IT can enhance communication capabilities which can lower information processing costs (Clemons, Reddi, Row; 1993) and this can lead to improved financial performance. Thus decentralized decision making can influence the causal relationship between IT investment and company performance by improving access to information and sharing data which leads to more effective responses.

The usage of IT in companies can provide the computer networks necessary for middle managers to instantaneously access relevant information that can help them to make effective decisions faster, using up-to-date information. This is in contrast with a formal approvals process 
which would move along several hierarchical levels of authority (Andersen \& Segars, 2001), where bureaucracies can introduce delays.

According to Batra (2006), the improvement in the quality of decision making at various levels can result in enhancing the overall organizational effectiveness. The summaries of the above explanations can be seen in the Table 3.

Table 3

Moderation of Decentralized Decision Making

Moderation

Make organizational procedures more cost effective (Andersen \& Segars, 2001); profitable business decisions and performance (Andersen \& Segars, 2001); lower information processing costs (Clemons, Reddi, Row; 1993)
Financial Performance

\section{Performance Perspective}

\footnotetext{
Make effective decision at a faster

2 time using the up-to-date

Internal Business Process Performance information available to them at that time, in contrast with formal approvals moving along several hierarchical levels of authority (Andersen \& Segars, 2001); firm’s ability to coordinate actions and this makes the firm's abilities more effective and enhance responsiveness; enhancing the overall organizational effectiveness (Batra, 2006)
}

3 Improve on firm innovation and Innovation \& Learning Performance performance (Hency, 1992; Kogut \& Zender, 1992; March, 1991); 
lead to the increase in innovative

capacity (Nonaka, 1994).

4 Decision makers can easily obtain data and information about the

Customer Performance business activities and sharing it in reciprocal information exchanges, that can lead to them to be able to make effective responses (Andersen \& Segars, 2001) especially to respond to customer enquiries; to identify the problems and opportunities faster (Andersen \& Segars, 2001); enhancing the overall organizational effectiveness (Batra, 2006)

Based on the above representations, it was posited that:

H2a: Decentralized decision making moderates the relationship between company's emphasis on the infrastructure IT investment and company's financial performance.

H2b: Decentralized decision making moderates the relationship between company's emphasis on infrastructure IT investment and company’s internal business process performance.

H2c: Decentralized decision making moderates the relationship between company's emphasis on infrastructure IT investment and company’s innovation and learning performance.

H2d: Decentralized decision making moderates the relationship between company's emphasis on infrastructure IT investment and company's customer performance. 


\subsection{Control Variable - Size}

To examine the relationship between IT investment and a company's performance, it is necessary to provide a control for the variable that could have an impact on the linkage in the relationship. Previous studies (Lee \& Bose, 2002; Libby \& Waterhouse, 1996) used company size as the control variable, measured by the number of employees. The reason for controlling size is that studies have found larger companies expended more on IT investment as a percentage of their revenues as compared to smaller companies (Mitra \& Chaya, 1996). The impact that a company's size could have on company performance was by deriving greater synergy effects from human and financial resource that could eventually lead to better performance (Wu et al., 2006). For example, a company’s size may have a significant relationship with its performance. Thus, by controlling the size of business by controlling the number of employees in the company, the nature of the relationship between IT investment and a company's performance can be ascertained. The research model for this study is shown in Figure 1. 


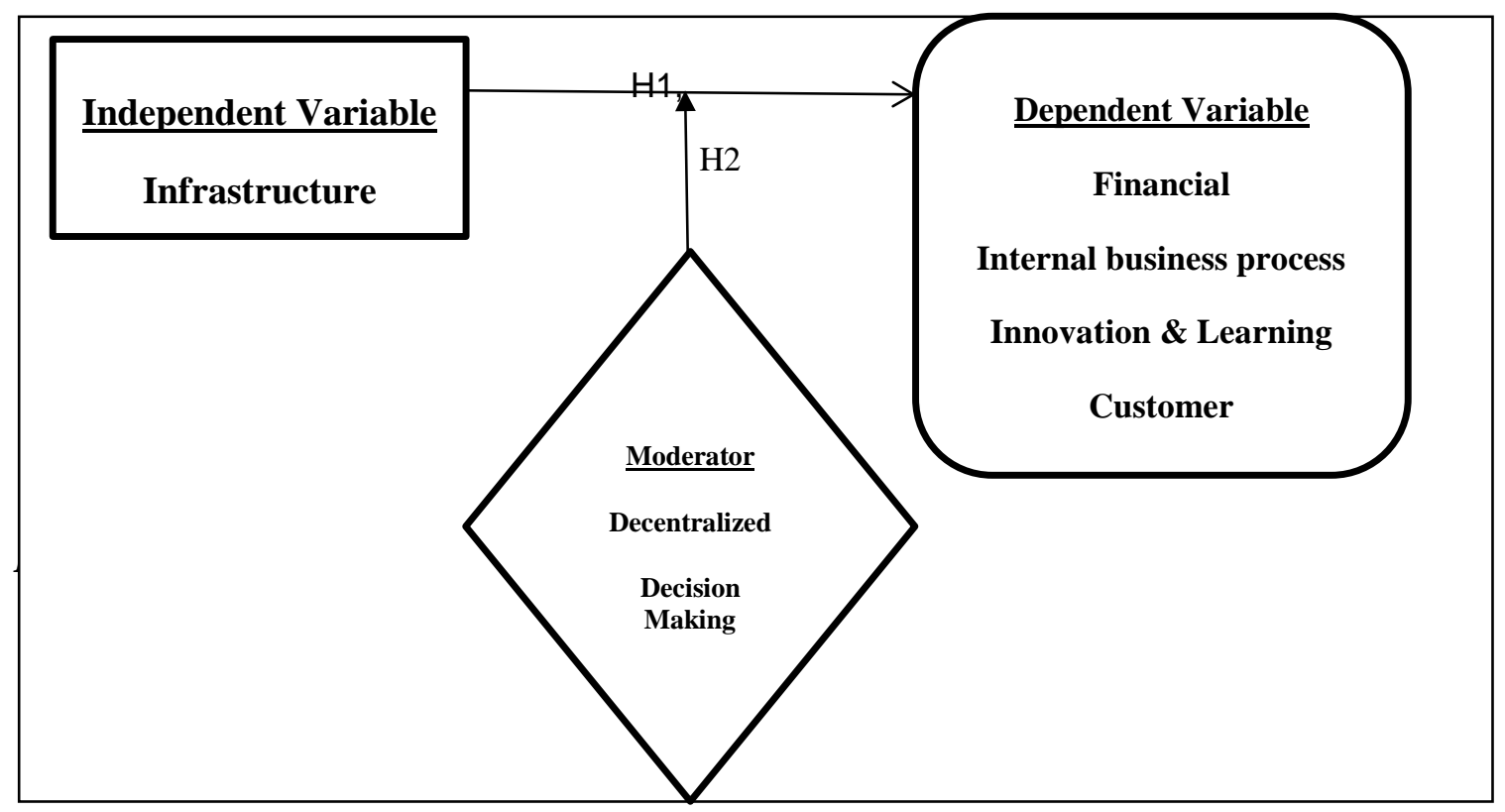

Control Variable: Size

Figure 1. Research model

\section{METHODOLOGY}

\subsection{Sample}

The data used in this study was drawn from a questionnaire-based survey of Malaysian Electrical and Electronic (E\&E) manufacturing companies. Sample companies from the E\&E sector were selected from the Malaysian Investment Development Authority (MIDA) listing which became the population frame for the study. The E\&E industry was selected because of its importance to employment, turnover and exports. The respondents in this study are represented by personnel in management positions such as Directors, Senior Managers and Accountants. They all have an understanding about company IT, management decisions and company performance. A total of 630 questionnaires were sent out with 102 responding. Of those, only 74 were usable, giving a usable response rate of $12.3 \%$. This relatively low response is quite common in Malaysia and is comparable with similar studies (Ruzita et al., 2006). 
Common method bias is a measurement error (Podsakoff, MacKenzie, Lee, \& Podsakoff, 2003; Podsakoff, MacKenzie, \& Podsakoff, 2012) that will give a bias to the presentation of the statistical results. This bias can be observed when looking at the presence of a systematic variance (Bagozzi \& Yi, 1990) that can lead to unsound conclusions.

One of the widely used method to test for the common method bias is Harman's single factor test (Podsakoff et al., 2003). All the variables will be loaded into an exploratory factor analysis (Andersson \& Bateman, 1997; Aulakh \& Gencturk, 2000) and the unrotated factor solution will be examined to determine the number of factors that are necessary to account for the variance in the variables. When a common method bias is presence, then the unrotated factor analysis will show that a single factor will emerge from the factor analysis or one item accounts for the majority of the variances in the model (Podsakoff et al., 2003).

\section{Table 4}

Harman's single factor test for Common Method Bias

\begin{tabular}{|l|r|r|r|}
\hline \multirow{2}{*}{ Component } & \multicolumn{3}{|c|}{ Initial Eigenvalues } \\
\cline { 2 - 4 } & \multicolumn{1}{c|}{$\begin{array}{c}\text { Total of } \\
\text { Variance }\end{array}$} & $\begin{array}{c}\text { Cumulative } \\
\%\end{array}$ \\
\hline 1 & 2.589 & 43.153 & 43.153 \\
2 & 1.066 & 17.772 & 60.925 \\
3 & .815 & 13.578 & 74.503 \\
4 & .597 & 9.950 & 84.453 \\
5 & .537 & 8.955 & 93.408 \\
6 & .396 & 6.592 & 100.000 \\
\hline
\end{tabular}

As shown in the Table 4, the majority of the variance was not accounted for by one general factor and the variance did not exceed a cut-off point of 50\% (Eichhorn, 2014; Podsakoff \& Organ, 1986). Thus common method bias was not evident in this study. 


\subsection{Measurements of Variables}

\subsubsection{IT Investment}

The respondents classified their IT investment is infrastructure or not. The questionnaires were adapted from a study (Weill \& Aral, 2006b) at Massachusets Instititute of Technology (MIT)’s website (http://web.mit.edu/cisr/MITCISR-ITPortfolio.doc). The qualitative aspects of the original questionnaire were modified to suit the purpose of this study. The respondents were also asked to specify the nominal amount expended annually for their IT investment.

\subsubsection{Moderator- Decentralized Decision Making}

This measurement was intended to measure the degree of decentralized decision making in any particular organization. The measurement was adapted from Andersen, (2005) which was made on the basis of reported indices measure of hierarchy of authority (Dewar, Whetten \& Boje, 1980). This scale refers to the measure of decision authority on the part of middle managers on getting approval from management before starting any important activities. Each item was accessed on a Likert scale ranging from 1 to 7 to ensure that any decentralization practices embraced by the company is being captured by this instrument, however big or small the degree of decentralization is. In this scale, the higher the number, the higher the decentralization levels are.

Principal Component Factor Analysis (PCFA) with varimax rotation was carried out for the five items of decentralized decision making measure. The results showed that Bartlett's Test of Sphericity (Bartlett, 1954) was significant (p-value < 0.01). Kaiser-Meyer-Olkin (KMO) measure of sampling adequacy was 0.70, which exceeded the recommended value of 0.5 (Kaiser, 
1974). There were five questions to assess the decentralized decision making. These five questions were asked using Likert scale of 1 (strongly agree) to 7 (strongly disagree). The scale is reversed in nature because it measures the degree of centralization and decentralization of decision making. The higher the scale, the more decentralized a firm is. The factor analysis on the five items of the dimension produced one dimension for this construct (Unidimensional). A reliability test for this dimension produced a Cronbach alpha of 0.78 which is acceptable (Nunnally, 1978).

\subsubsection{Company Performance}

The instrument to measure a company’s performance was adapted from Hoque et al., (2001) and which has also been used by other researchers (Fang \& Lin, 2006; Bradford \& Robert, 2001; Grover \& Davenport, 2001). Each dimension of the performance indicators comprises of multiple items specified under the four perspectives of BSC. The respondents were asked to indicate, on a five point Likert scale, ranging from one (decrease in performance) to five (increase in performance), the effect of performance across the four BSC dimensions in the last three years (Ruzita et al., 2006).

Principal Component Factor Analysis (PCFA) with varimax rotation was carried out for the 20 items of the company's performance measures. The results showed that Bartlett's Test of Sphericity (Bartlett, 1954) was significant (p-value < 0.01). Kaiser-Meyer-Olkin (KMO) measure of sampling adequacy was 0.84 , which exceeded the recommended value of 0.5 (Kaiser, 1974). Both of these results support the use of the data for further factor analysis. This was further subjected to varimax rotation and loading equal or greater than 0.7 for sample size $=60$ (Hair, Black, Babin, Andersen \& Tatham, 2006). Four distinct dimensions were extracted from 
the PCFA with eigenvalues exceeding 1.0. After several runs of factor analysis, five items were deleted from further factor analysis, these being employee satisfaction, market share, customer satisfaction, on time delivery and customer response time. These items were deleted because their factor loading was less than 0.7, which is required for sample size equal to 60 (Hair et al., 2006). These dimensions were renamed as internal business process measure, customer measure and financial measure and innovation \& growth. A reliability check was later performed on the items in the new dimensions, in order to determine the internal consistency of the measuring items. The values of Cronbach Alpha for component financial, internal business process, innovation \& growth and customer were $0.93,0.90,0.92$ and 0.89 respectively.

\section{RESULTS}

\subsection{Hierarchical Regression Analysis}

Hierarchical regression analysis was conducted, which tested the effect of the relationship between independent variables, dependent variables, control variables and moderator. In this study, size was treated as a control variable. Controlling for size provides a better test for a company's IT Investment and its impact on BSC measures. Regression was conducted for each of the BSC perspectives.

\subsection{Hierarchical Regression}

Hierarchical regression analysis was conducted, where it tested the effects of a relationship between the independent variable, the dependent variable and the control variable. Size was treated as a control variable. Regression was conducted for each of the BSC perspectives. 


\subsubsection{Result on the hypotheses testing: Financial performance (Hierarchical Regression)}

Table 5: Model Summary \& Coefficients

\begin{tabular}{|l|r|r|r|r|r|}
\hline Model & \multicolumn{1}{|c|}{$\mathrm{R}$} & R Square & \multicolumn{1}{c|}{$\begin{array}{c}\text { R Square } \\
\text { Change }\end{array}$} & F Change & Sig. F Change \\
\hline 1 & .203 & .041 & .041 & 3.085 & .083 \\
\hline 2 & .287 & .082 & .041 & 3.203 & .078 \\
\hline 3 & .291 & .084 & .002 & .148 & .702 \\
\hline 4 & .337 & .113 & .029 & 2.252 & .138 \\
\hline
\end{tabular}

\begin{tabular}{|l|l|r|r|r|}
\hline \multirow{2}{*}{ Model } & IV & & & \\
\hline 1 & Number of Employee & Beta & \multicolumn{1}{c|}{$\mathrm{t}$} & \multicolumn{1}{c|}{ Sig. } \\
\hline 2 & Number of Employee & -.203 & -1.756 & .083 \\
\hline & Infrastructure & -.214 & -1.877 & .065 \\
\hline & & .204 & 1.790 & .078 \\
\hline 3 & Number of Employee & & & \\
\hline & Infrastructure & -.219 & -1.898 & .062 \\
\hline & Moderator & .211 & 1.817 & .073 \\
\hline & & -.045 & -.385 & .702 \\
\hline 4 & Number of Employee & & & \\
\hline & Infrastructure & -.215 & -1.881 & .064 \\
\hline & Moderator & .613 & 2.102 & .039 \\
\hline & Interaction Moderator*Infrastructure & .182 & .957 & .342 \\
\hline Dependent Variable: Financial & & -1.501 & .138 \\
\cline { 2 - 5 } & & & \\
\hline
\end{tabular}

As shown in Table 5, when the financial measure serves as a dependent variable, model 1 and model 2 significantly explains $4.1 \%$ and $8.2 \%$ of the variance in financial perspective [F $=$ 3.085; 3.203, $\mathrm{p}<0.1]$. This indicates that an infrastructure objective provides significant positive impact on financial performance at Beta $=[0.204, \mathrm{p}<0.1]$. The results also indicate that company size is associated significantly with this perspective $(\mathrm{p}<0.1)$. This suggest that a company's size 
will influence the relationships between infrastructure IT investment with a company's financial performance. It also indicates that company size will not influence the outcome from the moderating effects in the relationship. Models 3 and 4, which have included the effects of moderator and interactions, were not significantly related to financial performance. Thus, only hypothesis H1a is supported, hypotheses H2a is not supported. The summary of the hypotheses and results are presented in Table 6.

Table 6: Hypotheses Summary (Financial performance)

\begin{tabular}{|l|l|l|}
\hline No & Hypotheses & Result \\
\hline $\mathbf{1}$ & $\begin{array}{l}\text { H1a: Company's emphasis on infrastructure IT investment is positively } \\
\text { related to the company's financial performance. }\end{array}$ & Supported \\
\hline $\mathbf{2}$ & $\begin{array}{l}\text { H2a: Decentralized decision making moderates the relationship between } \\
\text { company's emphasis on the infrastructure IT investment and company's } \\
\text { financial performance. }\end{array}$ & $\begin{array}{l}\text { Not } \\
\text { supported }\end{array}$ \\
\hline
\end{tabular}

\subsubsection{Result on the hypotheses testing: Internal Business Process performance} (Hierarchical Regression)

Table 7: Model Summary \& Coefficients

\begin{tabular}{|l|r|r|r|r|r|}
\hline Model & \multicolumn{1}{|c|}{ R } & R Square & $\begin{array}{c}\text { R Square } \\
\text { Change }\end{array}$ & F Change & Sig. F Change \\
\hline 1 & .075 & .006 & .006 & .407 & .525 \\
\hline 2 & .262 & .069 & .063 & 4.808 & .032 \\
\hline 3 & .276 & .076 & .008 & .585 & .447 \\
\hline 4 & .313 & .098 & .021 & 1.633 & .206 \\
\hline
\end{tabular}




\begin{tabular}{|l|l|r|r|r|}
\hline Model & IV & \multicolumn{1}{c|}{ Beta } & \multicolumn{1}{c|}{$\mathrm{t}$} & \multicolumn{1}{c|}{ Sig. } \\
\hline 1 & Number of Employees & -.075 & -.638 & .525 \\
\hline 2 & & & & \\
\hline & Number of Employees & -.089 & -.772 & .443 \\
\hline & Infrastructure & .251 & 2.193 & .032 \\
\hline 3 & & & & .504 \\
\hline & Number of Employees & -.078 & -.672 & .045 \\
\hline & Infrastructure & .237 & 2.038 & .447 \\
\hline & Moderator & .090 & .765 & .520 \\
\hline 4 & & & & .052 \\
\hline & Number of Employees & -.075 & -.646 & .143 \\
\hline & Infrastructure & .583 & 1.982 & .206 \\
\hline
\end{tabular}

Dependent Variable: Internal Business Process

As shown in the Table 7, when internal business process measures serve as a dependent variable, only Model 2 significantly explains $6.9 \%$ of variance in internal business process performance $(\mathrm{F}=4.808), \mathrm{p}<0.05)$. The results also indicate that infrastructure provides significant positive impact on internal business process performance at Beta $=0.251(\mathrm{p}<0.05)$. The results also indicate that size is not associated significantly with this perspective. However other models were not significantly related to internal business process performance. Thus, hypothesis H1b is supported whereas H2b is rejected. The summary of the hypotheses and results are presented in Table 8 below,

Table 8: Hypotheses Summary (Internal Business Process Perspective)

\begin{tabular}{|l|l|l|}
\hline No & Hypotheses & Result \\
\hline $\mathbf{1}$ & $\begin{array}{l}\text { H1b: Company's emphasis on the infrastructure IT } \\
\text { investment is positively related to the company's internal } \\
\text { business process performance. }\end{array}$ & Supported \\
\hline
\end{tabular}




\begin{tabular}{|l|l|l|}
\hline 2 & $\begin{array}{l}\text { H2b: Decentralized decision making moderates the } \\
\text { relationship between company's emphasis on infrastructure } \\
\text { IT investment and company's internal business process } \\
\text { performance. }\end{array}$ & Not supported \\
\hline
\end{tabular}

\subsubsection{Result on the hypotheses testing: Innovation and Growth performance (Hierarchical Regression)}

Table 9: Model Summary \& Coefficients

\begin{tabular}{|l|r|r|r|r|r|}
\hline \hline Model & \multicolumn{1}{c|}{ R } & R Square & $\begin{array}{c}\text { R Square } \\
\text { Change }\end{array}$ & F Change & Sig. F Change \\
\hline 1 & .138 & .019 & .019 & 1.401 & .240 \\
\hline 2 & .285 & .081 & .062 & 4.792 & .032 \\
\hline 3 & .291 & .084 & .003 & .256 & .615 \\
\hline 4 & .291 & .085 & .000 & .004 & .949 \\
\hline
\end{tabular}

\begin{tabular}{|l|l|r|r|r|}
\hline Model & IV & Beta & $\mathrm{t}$ & Sig. \\
\hline & & & & .240 \\
\hline 1 & Number of Employees & -.138 & -1.184 & .188 \\
\hline 2 & & & & .032 \\
\hline & Number of Employees & -.152 & -1.331 & .214 \\
\hline 3 & Infrastructure & .249 & 2.189 & .042 \\
\hline & Number of Employees & -.145 & -1.253 & .615 \\
\hline & Infrastructure & .240 & 2.070 & .217 \\
\hline & Moderator & .059 & .506 & .455 \\
\hline & & & & .801 \\
\hline & Number of Employees & -.145 & .1 .245 & .949 \\
\hline & Infrastructure & .223 & .0452 & .254 \\
\hline
\end{tabular}


As shown in the Table 9, when Innovation \& Growth serve as a dependent variable, all the models were not significant except for model 2 which significantly explains $8.1 \%$ of variance in Innovation \& Growth performance $(\mathrm{F}=4.792), \mathrm{p}<0.05)$. The results also indicated that infrastructure provides significant positive impact on Innovation \& Growth performance at Beta $=0.249(\mathrm{p}<0.05)$. The results also indicated that size was not associated significantly with this perspective. However other models were not significantly related to Innovation \& Growth performance. Thus, hypothesis H1c is supported whereas H2c is rejected. The summary of the hypotheses, results and discussions are presented in Table 10.

Table 10: Hypotheses Summary (Innovation \& Growth)

\begin{tabular}{|l|l|l|}
\hline $\mathbf{N o}$ & Hypotheses & Result \\
\hline $\mathbf{1}$ & $\begin{array}{l}\text { H1c: Company's emphasis on the infrastructure IT } \\
\text { investment is positively related to the company's innovation } \\
\text { and growth performance. }\end{array}$ & Supported \\
\hline $\mathbf{2}$ & $\begin{array}{l}\text { H2c: Decentralized decision making moderates the } \\
\text { relationship between company's emphasis on infrastructure } \\
\text { IT investment and company's innovation and growth } \\
\text { performance. }\end{array}$ & Not supported \\
\hline
\end{tabular}

5.1.4. Result on the hypotheses testing: Customer performance (Hierarchical Regression): Table 11: Model Summary \& Coefficients

\begin{tabular}{|l|r|r|r|r|r|}
\hline Model & R & R Square & \multicolumn{1}{c|}{$\begin{array}{c}\text { R Square } \\
\text { Change }\end{array}$} & F Change & Sig. F Change \\
\hline 1 & .128 & .016 & .016 & 1.199 & .277 \\
\hline 2 & .321 & .103 & .087 & 6.863 & .011 \\
\hline 3 & .370 & .137 & .034 & 2.740 & .102 \\
\hline 4 & .527 & .278 & .141 & 13.482 & .001 \\
\hline
\end{tabular}




\begin{tabular}{|l|l|r|r|r|}
\hline Model & IV & \multicolumn{1}{c|}{ Beta } & \multicolumn{1}{c|}{$\mathrm{t}$} & \multicolumn{1}{c|}{ Sig. } \\
\hline 1 & Number of Employees & -.128 & -1.095 & .277 \\
\hline 2 & & & & \\
\hline & Number of Employees & -.144 & -1.278 & .205 \\
\hline & Infrastructure & .295 & 2.620 & .011 \\
\hline 3 & Number of Employees & & & .282 \\
\hline & Infrastructure & .122 & -1.085 & .021 \\
\hline & Moderator & .187 & 1.655 & .102 \\
\hline & & & & .2 .357 \\
\hline 4 & Number of Employees & -.113 & -1.095 & .277 \\
\hline & Infrastructure & .153 & 4.383 & .000 \\
\hline & Moderator & -1.147 & -3.672 & .000 \\
\hline
\end{tabular}

Dependent Variable: Customer Perspective

As shown in the Table 11, when Customer measure served as a dependent variable, models 2 and 4 significantly explains $10.3 \%$ and $27.8 \%$ of variance in customer perspective $(\mathrm{F}=6.863$ and $\mathrm{F}=13.482, \mathrm{p}<0.05)$. The results also indicated that for model 2, infrastructure provides significant positive impact on customer performance at Beta $=0.295(\mathrm{p}<0.05)$. As for model 4, it showed that moderator was significant at $\mathrm{p}<0.05$. However other models were not significantly related to customer performance. Thus, hypothesis H1d and H2d are accepted. The summary of the hypotheses, results and discussion are presented in Table 12 below;

Table 12: Hypotheses Summary (Customer Perspective)

\begin{tabular}{|l|l|l|}
\hline No & Hypotheses & Result \\
\hline $\mathbf{1}$ & $\begin{array}{l}\text { H1d: Company's emphasis on the infrastructure IT } \\
\text { investment is positively related to the company's customer } \\
\text { performance.. }\end{array}$ & Supported \\
\hline
\end{tabular}




\begin{tabular}{|l|l|l|}
\hline 2 & $\begin{array}{l}\text { H2d: Decentralized decision making moderates the } \\
\text { relationship between company's emphasis on } \\
\text { infrastructure IT investment and company's customer } \\
\text { performance. }\end{array}$ & Supported \\
\hline
\end{tabular}

\subsection{DISCUSSION}

\subsection{Relationship between Infrastructure IT Investment and Performance}

The hierarchical multiple regression results revealed that infrastructure IT investment was significantly positively related with the financial (H1a) internal business process (H1b), innovation and growth (H1c) and customer performance (H1d). These findings support the findings in previous studies (Weill \& Aral, 2003; 2004; 2006a, 2006b; Weill \& Johnson, 2005; Weill \& Broadbent, 1998) which stated that infrastructure IT investment brought different and diverse benefits to the organization. Benefits of infrastructure investments were business integration, business flexibility, reduced marginal costs and standardization (Weill \& Broadbent, 1998). Infrastructure IT investment also serves as a foundation for shared IT services (Weill \& Aral, 2004).

With regard to the relationships of infrastructure IT investment to company performance, various authors have suggested how this could be achieved. Reducing cost, which relates to an increase in the financial perspective (Weill \& Broadbent, 1998). Increase in internal business process measure could be achieved by facilitating greater business processing and management (Weill \& Woodham, 2002). Increase in innovation and growth performance could be achieved when infrastructure IT can enable future IT initiative (Weill \& Aral, 2004). Finally an increase for customer performance could be achieved by making infrastructure IT as a source of 
competitive advantage (Weill et al, 2002). IT infrastructure could serve as a platform for a shared customer database (Weill \& Aral, 2004) and to reduce time to market for new business initiatives. All these explanations are provided to explain the significant findings from this study with regard to the relationship between infrastructure IT investment and company performance. Based on the above explanations, infrastructure IT investment will lead to improvements in the all perspectives of BSC as shown by the findings of this study. Infrastructure IT investment will also lead to improvements in the all perspectives of BSC as shown by the findings of this study.

\subsection{Moderating effect of Decentralized decision making}

As can be seen in the statistical output (Tables 5, 7, 9 and 11), all the relationships were not significant for model 3, that is where moderator was included to test for the moderating effect. This clearly indicates that decentralized decision making does not have bring any significant moderating effect to the financial, internal business process and customer performance perspectives. Since the moderator has a negligible correlation with the criterion variable, decentralized decision making could not be considered as quasi moderator as, for moderator to be termed as quasi moderator, it must interact with the criterion variable itself (Sharma, Durand \& Gur-Arie, 1981).

If we were to look further into the statistical output (Table 5, Table 7, Table 9, Table 11), we can see that all the relationships were not significant for model 4 except for customer (H2d) perspective. For model 4, it showed that the moderator was significant at $\mathrm{p}<0.05$ and the interaction effect of infrastructure IT with moderator is also significant at $p<0.05$. Since the moderator had a significant influence on the relationship between categories of IT investment with customer performance in model 3 and model 4, upon the introduction of moderator, and 
also upon the interaction effects of moderator with infrastructure IT, we can deduce that the moderator is a pure moderator. According to, a variable is termed as pure moderator variable when it enters into interaction with predictor variables, while having a negligible correlation with the criterion itself (Sharma et al., 1981; Cohen \& Cohen, 1977).

The moderating effects of decentralized decision making on IT investment and customer perspective are that decision makers can utilize decentralized decision making to obtaining data about business activities and act upon that information. This can lead to them being able to make effective responses (Andersen \& Segars, 2001), especially responding to customer enquiries, identifying problems and opportunities faster (Andersen \& Segars, 2001) and in enhancing overall organizational effectiveness (Batra, 2006). The plausible explanations would be that these benefits from the moderating effects would have an effect on the relationship between infrastructure IT investment and customer perspective and thus produce the significant finding on this relationship. Based on these explanations, this has answered RQ.3.

\subsection{Effect of sample size}

Size is based on the number of employees (Lee \& Bose, 2002; Libby \& Waterhouse, 1996; Mitra \& Chaya, 1996; Weill \& Aral, 2004; Wu et al, 2006). Size is used as the controlling variable in this study to determine whether it has any significant impact on the relationship between IT investment and company performance, and also on the moderating effects of decentralized decision making Thus, by taking size as a control variable, the nature of relationship between IT investment and firm performance can be explored. Based on the data in the hierarchical regression analysis (Tables 5, 7, 9 and 11), it can be seen from model 1 that size does not have any significant effects on the relationships except on the relationship between infrastructure IT investment and financial performance. This means that the size of the company 
will bring significant effects on the relationship between infrastructure IT investment and financial performance. Based on these data, we can say that the size of the company will not significantly influence the relationships between infrastructure IT investment and other perspectives; namely internal business process, innovation \& growth and customer perspectives. This explanation has answered on the RQ.2.

\subsection{Limitations of the Study}

This study has several limitations. The first limitation pertains to the sample. The sample is rather limited and samples are only taken from MIDA's list. The sample is also relatively small and confined to E \& E manufacturing firms only, thus would provide a potential source of bias to generalizability to manufacturing sectors in general. Secondly the limitation relates to the low response from mail-surveyed questionnaire. A common problem faced is the difficulty to ensure that respondents answer the questionnaire. The low response rate has indicated that they were not too enthusiastic in replying to the mailed questionnaire.

\subsection{Conclusion}

To conclude, this study has shown the benefits of relating infrastructure IT investments with company's multidimensional performance. This study has demonstrated that infrastructure IT investment can bring different benefits to a company, both tangible and intangible. These benefits can be both financial and non-financial in nature. Decentralized decision making only moderated the customer perspective only, it had negligible effects on other perspectives.

This study has provided additional evidence related to the issue of the infrastructure IT productivity paradox and the moderating role of decentralized decision making to the 
relationship between infrastructure IT investment and firm's performance within the Malaysian electrical and electronics sector.

\section{Acknowledgements}

The authors would like to express appreciation to the Malaysian Government and MARA University of Technology (UiTM) for funding this research. 


\section{References}

Andersen, T. J. (2005). The performance effect of computer mediated communication \& decentralized strategic decision making. Journal of Business Research, 58(8), 1059-1067.

Andersson, L. M., \& Bateman, T. S. (1997). Cynicism in the workplace: Some causes and effects. Journal of Organizational Behavior, 18, 449- 469.

Andersen T. J. \& Segars, A. H. (2001). The impact of IT on decision structure and firm distinction in social psychological research performance: Evidence from the textile and apparel industry. Inf. Manage, 39, 85100.

Appleton, E. (1997). How to survive ERP. Datamation, 43(3), 50-53.

Aulakh, P. S., \& Gencturk, E. F. (2000). International principal-agent relationships-control, governance and performance. Industrial Marketing Management, 29, 521-538.

Bagozzi, R. P., \& Yi, Y. (1990). Assessing method variance in multitrait-multimethod matrices: The case of selfreported affect and perceptions at work. Journal of Applied Psychology, 75(5), 547-560. doi: 10.1037/0021-9010.75.5.547.

Banker, R. D., H. Chang, and M. J. Pizzini. (2004). “The Balanced Scorecard: Judgmental Effects of Performance Measures Linked to Strategy.” The Accounting Review, 79 (1): 1-23.

Barad, M., and S. Dror. (2008). “Strategy Maps as Improvement Paths of Enterprises.” International Journal of Production Research, 46 (23): 6627-6647.

Bardhan, I., Krishnan, V., and Lin, S. (2013). "Business value of information technology: Testing the interaction effect of IT and R\&D on Tobin’s Q,” Information Systems Research, (24:4), pp.1147-1161.

Barney, J.(1991), “Enterprise resources and sustained competitive advantage,” Journal of Management, 17(1): 99-120.

Barney, J., Wright, M., \& Ketchen, D.J., (2001), The resource based view of the firm: Ten Years after 1991, Journal of Management, 27 (6), 625-641.

Baron, Reuben M. and David A. Kenny. (1986). "The moderator-mediator variable: conceptual, strategic, and statistical considerations." Journal of Personality and Social Psychology, 61(6): 1173-1182.

Bartlett, M. S. (1954). A note on the multiplying factors for various chi square approximations. Journal of the Royal Statistical Society, 16 (Series B), 296- 298. 
Barua, A. \& Kriebel, C. H. (1995). Information technologies and business value-An analytic and empiricalinvestigation. Information Systems Research, 6(1), 3-23.

Barua, A., Kriebel, C. H., \& Mukhopadhyay, T. (1995). Information technologies and business value: An analytic and empirical investigation. Information Systems Research, 6(1), 3-23.

Barua, A., \& Mukhopadhyay, T. (2000). "Information Technology and Business Performance: Past, Present, and Future," in Framing the Domains of Information Technology Management: Projecting the Future...Through the Past, R. W. Zmud (ed.), Cincinnati, OH: Pinnaflex Press, pp. 65-84.

Batra, S. (2006). Impact of IT on organizational effectiveness: A conceptual framework incorporating organizational flexibility. Global Journal of Flexible System Management, 7(1\&2), 15-25.

Benjamin, R. I (1993). "Managing information technology enabled change," in Human organizational and social dimensions of information systems development, D. Avison, J. Kendall, and J. I. DeGross, J. (eds.), North Holland, Amsterdam, 381-398.

Bharadwaj, A., Bharadwaj, S., \& Konsynski, B. (1999). Information technology effects on firm performance as measured by Tobin’s q, Management Science, 45 (6), 1008-1024.

Bradford, M. and Roberts, D. (2001). Does your ERP measure up? Strategic Finance, (83:3), 30-34.

Broadbent, M., \& Butler, C. (1995). Implementing business process redesign: Early lessons from the Australian experience, Australian Journal of Information Systems, (2:2), 63-76.

Brynjolfsson, E. (1993). The productivity paradox of information technology. Communications of the ACM, 36(2), 67-77.

Brynjolfsson, E. (1996). The contribution of IT to consumer welfare. Information System Research, 7(3), 281:300.

Brynjolfsson, E. (2003). The IT productivity gap. http://ebusiness.mit.edu/erik/Optimize/pr_roi.html.

Brynjolfsson, E., \& Hitt, L. (1993). Is information systems spending productive? New evidence and new results. Proceedings of the Fourteenth International Conference on Information Systems , 47-64. Orlando, FL.

Brynjolfsson, E., \& Hitt, L. (1995). Information technology as a factor of production: The role of differences among firms. Economics of Innovation and New Technology, 3(4), 183-200.

Brynjolfsson, E., \& Hitt, L. (1996). Paradox lost? Firm-level evidence on the returns to information systems spending. Management Science, 42(4), 541-558.

Brynjolfsson, E. \& Hitt, L. (2000). "Beyond Computation: Information Technology, Organizational Transformation and Business Performance,” Journal of Economic Perspectives, vol. 14, no. 4, pp. 23-48, Autumn, 2000. 
Brynjolfsson, E., \& Yang, S. (1997). The intangible benefits and costs of investments: Evidence from financial markets. Proceedings of the Eighteenth International Conference on Information Systems, 147-166. Atlanta, GA, USA.

Bureau of Economic Analysis. (2007). Table 5.3.5: Private fixed investments by type. Retrieved from http://www.bea.gov/bea/dn/nipaweb/TableView.asp?

Burgelman, R. A. (1983). A model of the interaction of strategic behavior, corporate context, and the concept of strategy. Academy Management Review, 8, 61-70.

Cameron, K. S. (1986). Effectiveness as paradox: Consensus and conflict in conceptions of organizational effectiveness. Management Science, 32, 539-55.

Campbell, M, (2012). What a Difference a Year Makes: Time Lag Effect of Information Technology Investment on Firm Performance. Journal of Organizational Computing and Electronic Commerce. 22, 237-255.

Clemons, E.K, Reddi S.P., \& Row M.C. (1993). The impact of information technology on the organization of economic activity: the move to the middle: hypothesis, Journal of Management Information Systems, 10, 9-35.

Cohen, J., \& Cohen, P. (1977). Applied multiple regression/correlation analysis for the behavioural science. New York: Wiley \& Sons.

Cunningham, J. B. (1978). A systems resource approach for evaluating organizational effectiveness. Human Relations, 31(7), 631-656.

Davenport. T. (1993). Process innovation: Reengineering work through IT, Harvard Business School Press, Boston.

Dedrick, J., Gurbaxani, V., and Kraemer, K. L. (2003). "Information Technology and Economic Performance: A Critical Review of Empirical Evidence,” ACM Computing Surveys, (35:1), pp. 1-28.

Dewan, S., \& Min, C. (1997). The substitution of information technology for other factors of production: A firm level analysis. Management Science, 43(12), 1660-1675.

Dewar, R., Whetton, D. \& Boje, D. (1980). "Reliability and validity of scales of centralization, formalization, and control, Administrative Science Quarterly, 25(1) (March): 120-128.

Dos Santos, B.L., \& Peffers, K. (1995). Rewards to investors in innovative information technology applications. First movers and early followers in ATMs. Organizational Science, 6(3), 241-259.

Duncan, N.B. (1995). Capturing flexibility of IT infrastructure: A study of resource characteristics and their measure, Journal Management Information System,12(2),37-57.

Earl, M. J., \& Kuan, B.(1994) "How New is Business Process Redesign?" European Management Journal,(12:1), 20-30. 
Edwards, J. B. (2001). ERP, balanced scorecard and IT. How do they fit together? Journal of Corporate Accounting \& Finance, 12(5), 3-12.

Eichhorn, B. R. (2014). Common method variance techniques. Retrieved from https://www.mwsug.org/proceedings/2014/AA/MWSUG-2014-AA11.pdf.

Fang, M. Y., \& Lin, F. (2006). Measuring the performance of ERP System - from the balanced scorecard perspectives. The Journal of American Academy of Business, 10(1), 256-263.

Fernandes, K. J., V. Raja, and A. Whalley. 2006. "Lessons from Implementing the Balanced Scorecard in a Small and Medium Size Manufacturing Organization.” Technovation, 26 (5-6): 623-634.

Fulk, J., \& Desanctis G. (1995). Electronic Communication and changing organizational forms, Organization Science, 6, pp. 337-349.

Garud, R., \& Kumaraswamy, A. (2005). Vicious and virtuous circles in the management of knowledge: The case of InfoSys Technologies. MIS Quarterly, 29(1), 9-33.

Grover, V. \& Davenport. (2001). T. H., General perspectives on knowledge management: Fostering a research agenda, Journal of Management Information Systems, 18(1), 5-21.

Hair, J. F., Black, W. C., Babin, B. J., Anderson, R. E., \& Tatham, R. L. (2006). Multivariate data analysis. New Jersey: Pearson Prentice Hall.

Hamilton, C., \& Chervany, N. L. (1981). Evaluating information system effectiveness - Part 1: Comparing evaluation approaches. MIS Quarterly, 5(3), 55-69.

Hency, J. (1992). Creative capabilities and experiential learning, in: J. Mulligan, C. Griffin(Eds.), Empowerment through experiential learning: Explorations of good practice, Kogan Page, London.

Hitt L.M. \& Brynjolfsson E. (1995). Productivity, profit, and consumer welfare: Three different measures of Information technology's value. MIS Quarterly, 20(2), 121 - 143.

Hitt, L.M. \& Brynjolfsson. E. (1996). Productivity, business profitability and consumer surplus. Three different measures of IT value. MIS Quarterly, (20)2, 121-142.

Hoque, Z. \& James, W. (2000). Linking balanced scorecard measures to size and market factors: Impact on organizational performance. Journal of Management Accounting Research, 12, 1-17.

Hoadley, E., and Kohli, R. (2014). "Business Value of IS Investments,” Chapter 71 in Computing Handbook, Third Edition: Information Systems and Information Technology, H. Topi and A. Tucker (eds.), Boca Raton, FL: CRC Press.

Hoque, Z., Mia, L,. \& Alam, M. (2001). Market competition, computer aided manufacturing and use of multiple performance measures: An empirical study. British Accounting Review, 33, 23-45. 
Huber, G. P. (1990). A theory of the effects of advanced information technologies on organizational design, intelligence, and decision making. Academy Management Review, 15, 47-71.

Hwang, J.S; Kim, S.H. \& Lee, H. (2015). Breaking the Myths of the IT Productivity Paradox. Ksii Transactions On Internet And Information Systems, Vol. 9, NO. 1.

Jeffery, M., \& Leliveld, I. (2004). Best practices in IT portfolio management. MIT Sloan Management Review, 45(3), 41-49.

Kaiser, H. (1974). An index of factorial simplicity. Psychometrica, 39: 31-36.

Kaplan, R. S., \& Norton, D. P. (1992). The balanced scorecard-measures that drive performance. Harvard Business Review, 70(1), 71-79.

Kaplan, R. S., \& Norton, D. P. (1993). Putting the balanced scorecard to work. Harvard Business Review, 71(5), 134-142.

Kaplan, R. S., \& Norton, D. P. (1996). The balanced scorecard-translating strategy into action. Boston, MA: Harvard Business School Press.

Kaplan, R. S., \& Norton, D. P. (2001). Transforming the balanced scorecard from performance measurement to strategic management: Part 1. Accounting Horizons, March: 87-104.

Kaplan, R. S., and D. P. Norton. (2004). Strategy Maps. Boston, MA: Harvard Business School Press.

Kaplan, R. S. (2009). Conceptual foundations of the balanced scorecard. In Handbook of Management Accounting Research, Volume 3, edited by Chapman, C. S., A. G. Hopwood, and M. D. Shields, 12531269. Oxford, U.K.: Elsevier.

Katz, D., \& Kahn, R. L. (1966). The social psychology of organizations, New York: Wiley.

Kenny, D.A. (2013). Moderator Variables. Retrieved from http://davidakenny.net/cm/moderation.htm.

Khan, S. (2012). Centralized and decentralized organizational structure. Retrieved from http://www.ehow.com/about_6517661_centralized-decentralized-organizational-structure.html.

Kogut, B \& Zander, U. (1992). Knowledge of the firm, combinative capabilities, and the replication of technology. Organization Science ,3, 383-397.

Kohli, R., and Devaraj, S. (2003). "Measuring Information Technology Payoff: A Meta Analysis of Structural Variables in FirmLevel Empirical Research,” Information Systems Research, (14:2), pp. 127-145. 
Kohli, R., Devaraj, S, Ow. T.T. (2012). Does information technology investment influence a firm's market value? A case of non publicly traded healthcare firms. MIS Quarterly, 36(4), 1145-1163.

Lawrie, G and Cobbold, I (2004) Third Generation Balanced Scorecard: evolution of an effective strategic control tool, International Journal of Productivity and Performance Management, Vol 53, No 7, pp. 611-623.

Lee J. Yao, Chunhui, L., \& Siew, H. C. (2010). The influence of firm specific context on realizing information technology business value in manufacturing industry. International Journal of Accounting Information Systems, 11 (4), December, 353-362.

Lee, J., \& Bose, U. (2002). Operational linkage between diverse dimensions of information technology investments and multifaceted aspects of a firm's economic performance. Journal of Information Technology, 17, 119-131.

Libby, T., \& Waterhouse, J. H. (1996). Predicting change in management accounting systems. Journal of Management Accounting Research, 8, 137-150.

Lin, W. T. \& C. Chiang. (2011). “The impacts of country characteristics upon the value of information technology as measured by productive efficiency.” International Journal of Production Economics. 132(1):13-33.

Lin, W.T. \& Chuang, C.H., (2013). Investigating and comparing the dynamic patterns of the business value of information technology over time. European Journal of Operational Research, 228, 249-261.

Mabert, V. A., Soni A. and Venkatarmanan, M. A., (2000). Enterprise resource planning survey of U.S. manufacturing firms, Production and Inventory Management, 41(2), 52-58.

Mahmood, M. A., \& Mann, G. J. (1993). Measuring the organizational impact of information technology investment: An exploratory study. Journal of Management Information Systems, 10(1), 97-122.

Maiga, A. S., \& Jacobs, F. A. (2003). Balanced scorecard, activity based costing and company performance: An empirical analysis. Journal of Managerial Issues, 15(3), 283-301.

March, J.G. (1991). Exploration and exploitation in organizational learning, Organizational Science, 2, 71-87.

Melville, N., Kraemer, K., \& Gurbaxani, V. (2004). Information technology and organizational performance: an integrative model of IT business value, MIS Quarterly, 28 (2), 283-322.

Mintzberg, H. (1978). Patterns in strategy formation. Management Science, 24, 934-948.

Mithas, S., Tafti, A., Bardhan, I., and Goh, J. M. (2012). "Information technology and firm profitability: mechanisms and empirical evidence,” MIS Quarterly (36:1), pp. 205-224.

Mitra, S., \& Chaya, A. K. (1996). Analyzing cost-effectiveness of organizations: The impact of information technology spending. Journal of Management Information Systems, 13(2), $29-57$.

Nonaka, I. (1994). A dynamic theory of organizational knowledge creation, Organization Science, 5, 14-37. 
Nunnally, J. (1978). Psychometric theory. New York: Mcgraw Hill.

Oztaysi, B. \& I. U. Sari. (2009). “Comparing MADM Techniques for Use in Performance Measurement.” In: ISAHP 2009 Proceedings. The 10th International Symposium on the Analytic Hierarchy Process, 29 July-1 August 2009. 53-64. Pittsburgh, PA: Creative Decisions Foundation.

Öztayşi, B., T. Kaya, \& C. Kahraman. (2011). "Performance Comparison Based on Customer Relationship Management Using Analytic Network Process.” Expert Systems with Applications, 38 (8): 9788-9798.

Peppard, J., \& Rowland, P. (1995). The essence of business process engineering. London: Prentice Hall.

Podsakoff, P. M., MacKenzie, S. B., Lee, J.-Y., \& Podsakoff, N. P. (2003). Common method biases in behavioral research: A critical review of the literature and recommended remedies. Journal of Applied Psychology, 88(5), 879-903. doi: 10.1037/0021-9010.88.5.879.

Podsakoff, P. M., MacKenzie, S. B., \& Podsakoff, N. P. (2012). Sources of Method Bias in Social Science Research and Recommendations on How to Control It. Annual Review of Psychology, 63(1), 539-569. doi: doi:10.1146/annurev-psych-120710-100452.

Podsakoff, P.M., \& Organ, D.W. (1986). Self-reports in organizational research: Problems and prospects. Journal of Management, 12, 69-82.

Rigby, D., \& B. Bilodeau. 2015. Management Tools and Trends 2015. Boston, MA: Bain \& Company.

Ruzita Jusoh., Daing Nasir Ibrahim., Yuserrie Zainuddin. (2006). Assessing the alignment between business strategy and use of multiple performance measures using interaction approach. The Business Review, 5(1), 51-60.

Sambamurthy, V., Bharadwaj, A. \& V. Grover (2003). Shaping agility through digital options: Reconceptualizing the role of IT in contemporary firms. MIS Quarterly, 27(2), 237-263.

Sami, D. (2010). Training seen as key to employee satisfaction, success. Retrieved from http://www.ocregister.com/articles/training-256561-employees-skills.html.

Schryen, G. (2013). "Revisiting IS Business Value Research: What We Already Know, What We Still Need to Know, and How We Can Get There,” European Journal of Information Systems (22:2), pp. 139-169.

Sharma, S., Durand, R. M., \& Gur- Arie, O. (1981). Identification and analysis of moderator variables. Journal of Marketing Research, 18, 291-300.

Sircar, S., Turnbow, J. L., \& Bordoloi, B. (2000). A framework for assessing the relationship between information technology investments and firm performance. Journal of Management Information Systems, 16(4), 6997.

Stiroh, Kevin J. (2002). "Information Technology and the U.S. Productivity Revival: What Do the Industry Data Say?” American Economic Review, 92 (5): 1559-76. 
Strassman, P. (1999). Information Productivity- Assessing the Information Management Costs of U.S. Industrial Corporations. New Canaan, CT.: Information Economics Press.

Stratopoulos, T., \& Dehning, B. (2000). Does successful investment in IT solve the productivity paradox? Information \& Management, 38, 103-117.

Tayler, W. (2010). The balanced scorecard as a strategy evaluation tool: The effects of implementation involvement and a causal-chain focus. The Accounting Review, 85 (3): 1095-1117.

Thouin, Mark F.; Hoffman, James J.; Ford, Eric W. (2008). The effect of information technology investment on firm-level performance in the health care industry. Health Care Management Review: January/March, 33(1) , 60-68.

Trang, Irvan. (2016). Competitive strength and its impact toward achieving company's performance based on balanced scorecard approach in the furniture industry in central Minahasa Regency. Journal of Life Economics. 3(2), p87-100.

Turner, J., \& Lucas Jr., H. C. (1985). Developing strategic information systems. In Guth, W. (Ed.), Handbook of business strategy . Boston: Warren, Gotham and Lamont.

Weill, P. (1992). The relationship between investment in information technology and firm performance: A study of valve manufacturing sector. Information System Research. 3(4), 307-332.

Weill, P., \& Aral, S. (2003). Managing the IT portfolio (Update circa 2003). MIT Sloan Management Review (Research Briefing), III(1C).

Weill, P., \& Aral, S. (2004). Managing the IT portfolio: Returns from the different IT asset classes. MIT Sloan Management Review (Research Briefing), IV(1A).

Weill, P., \& Aral, S. (2006). Generating premium returns on your IT investments. MIT Sloan Management Review, 47(2), 39-48.

Weill, P., \& Broadbent, M. (1998). Leveraging the new infrastructure: How market leaders capitalize on IT. Boston: Harvard Business School Press.

Weill, P., \& Johnson, A. (2005). “Managing the IT Portfolio (update Circa 2005): Where did the infrastructure go?” CISR Research Briefing, Sloan School of Management, MIT. 5(3A).

Weill, P., Subramani, M., \& Broadbent, M. (2002). IT infrastructure for strategic agility. CISR Working Paper No. 329.

Weill, P. \& Woodham, R. (2002). Don't Just Lead, Govern: Implementing Effective IT Governance. CISR WP No. 326. 
Westerman, G. (2004). Is virtual education as good as a classroom? CISR Research Briefing, Sloan School of Management, MIT. IV(2D).

Worldwide IT Trends \& Benchmark Report. (2001). Rubin Systems Inc. /META Group.

Wu, F., Yeniyurt, S., Kim, D., \& Cavusgil, S. T. (2006). The impact of information technology on supply chain capabilities and firm performance: A resource-based view. Industrial Marketing Management, 35(4), 493504.

Yuchtman, E., \& Seashore, S. E. (1967). A system resource approach to organizational effectiveness. American Sociological Review, 32(6), 891-903.

Yuhn, Kyhyang \& Park, Seung, R. (2010). Information technology, organizational transformation and productivity growth: An examination of the Brynjolfsson-Hitt proposition. Asian Economic Journal, 24(1), 87-108.

Zhu, K., \& Kraemer, K.L. (2002). E-commerce metrics for net enhanced organizations: Assessing the value of e commerce to firm performance in the manufacturing sector. Information System Research, 13(3), 27-295. 